\title{
Identification and Mapping of Readiness of Micro and Small Coffee Industry Cluster Development
}

\author{
Lya Aklimawati ${ }^{1 *}$, Djoko Soemarno ${ }^{1)}$, dan Surip Mawardi ${ }^{1)}$ \\ ${ }^{1)}$ Indonesian Coffee and Cocoa Research Institute, J1. PB. Sudirman 90, Jember Indonesia \\ ${ }^{*}$ Corresponding author: lya.akli@gmail.com \\ Received: 22 October 2015 / accepted: 06 November 2015
}

\begin{abstract}
Cluster development of micro and small-scaled coffee industry is an effort to improve the economy of community by utilizing local resources. This study was aimed to identify phase of cluster growth through determinant factors of industrial cluster growth; to assess a linkage between economy players in the industrial cluster; and to identify strength, weakness, opportunity, and threat in coffee industry development. This research was carried out in Sumberwringin, Bondowoso District, East Java. Survey method through direct observation and interviews were conducted in this study. Data collected included primary and secondary data. Number of respondents were 25 industry players selected by judgement sampling method. The data were analyzed by exploratory descriptive with content analysis method. This research concluded that industrial cluster studied was still in phase of formation and initiative (embryo) and its growth pattern followed Pattern III. Interrelationship between core industries has not been established, while linkage between core industries and supporting industries had already well-established. Strength and opportunity in coffee industry development included raw materials availability, market segment growth. Small and micro enterprises credit facility, supporting facility, and labor availability. Constraints and threat faced by coffee industry included limited market access, in adequate machineries, limited working capital, raw materials quality, inconsistent product quality, credit claim, and competitors.
\end{abstract}

Key words: industrial cluster, coffee, micro and small-scaled industry, cluster growth, Bondowoso

\section{INTRODUCTION}

To develop local economy potency, development of agro-industrial sector is very crucial, especially to improve the economy of community in a region. Agro-industrial sector is considered very influential toward the achievement of goals and objectives of regional development because it is directly related to all activities in agribusiness system, either upstream or downstream (Junaidi et al., 2014). Agroindustry is also considered to have comparative advantages which is translated through the use of materials from local resources (Supriyati \& Suryani, 2006). Making agricultural sector as the basis in industrial development will have wide impact on economic growth as well as social impact in the society.

Agro-industrial sector can be developed by invigorating micro, small, and medium enterprises (UMKM), because most UMKM in Indonesia are in the field of agroindustry (INDEF, 2011 cit Junaidi et al., 2014). In economic structure, contribution of UMKM 
in strengthening national economy is quite substantial (Sudaryanto et al., 2013). The important role of UMKM in economy development of a country is also reported by Demirbag et al. (2006). Beside its role in macroeconomic growth, UMKM also potentially encourages local economic growth and empowered the community in production activities.

It should also be noted that the opportunity of UMKM to develop productive sectors comes with vulnerability of UMKM in facing tight competition in globalization era. It is reflected from the general characteristic of UMKM which is income gathering or to increase income. Such characteristics of UMKM include family ownership, use of simple technology, limited access to capital, and no separation between business capital and personal needs (Sudaryanto et al., 2013). These characteristics are fundamental problems faced by most UMKM. Therefore, effort to develop competitive UMKM is performed through industrial cluster approach, especially in expanding business network.

One of the regions which use industrial cluster approach in empowering local UMKM is Bondowoso Regency. Development of this industrial cluster is a follow up of coffee-based economic cluster program. Considering the success of the technology overseeing in improving quality and marketing system in upstream sector, this economic cluster program is also intended to develop coffee downstream sector in Bondowoso Regency. To develop micro and small enterprises in an industrial cluster, characteristics, strengths, and abilities of micro small enterprises should be determined. This study will produce information related with the readiness of micro small-scale coffee downstream industry to be developed by cluster approach. This study was aimed to identify cluster growth stages through determinants of industrial cluster development, to review the relation between economic actors in the industrial cluster, and to identify strengths, constrain, opportunities, and threats in developing coffee industry.

\section{MATERIALS AND METHODS}

\section{Framework}

The cluster concept introduced by Porter (1990) is defined as centralization of similar industries which cooperate, compete, and interrelated in a geographic area by involving core industries and supporting industries. Institutions in industrial cluster include material suppliers up to downstream (market or exporter), service providers, business association, government agencies, research institutions, educational institutions and other related institutions which support the activities of companies in the cluster (Djamhari, 2006). In principle, development of industrial cluster is aimed to improve industrial competitiveness to face tight business competition in the globalization era. To improve industrial competitiveness, the cluster concept will also be implemented to micro small-scale coffee downstream industry in Bondowoso Regency.

The success of implementation of cluster concept starts with empowering the coffee upstream sector, then coffee downstream industry is developed using the same concept. Guiding institutions involved in Coffee-based Economic Cluster Model (Aklimawati et al., 2015) agree to socialize cluster system in coffee downstream sector. By cluster system, guiding institutions will be able to provide various facilities to the industry more easily. The facilities which had been given to farmer groups to develop the upstream sector were facilities which had direct and indirect impacts. Facilities with direct impact included pro- 
duction facilities and bank credit, while facilities with indirect impact included guidance, training, and dissemination of technology. The facilities would be provided to develop the downstream sector.

By providing the facilities, micro smallscale coffee downstream industry was expected to grow into a cluster to expand the business dynamics by considering local socio-cultural condition. Before forming industrial cluster, characteristics of coffee downstream industry should be mapped and determinants of cluster growth should be identified. It was aimed to discover the readiness of coffee downstream industry to be developed into a cluster. Identification of cluster formation factors referred to dynamic cluster approach by Rosenfeld (1997), which included specialization; research and development capacity; knowledge and skill; human resources development; closeness to supplier; availability of capital; network and social capital; entrepreneurship; and leadership and common vision. To determine cluster growth stages, cluster growth stage theory (life cycle) by EU-Commission in 2002 presented in Figure 1 (Suryono, 2012) was used.

\section{Research Location and Period}

This study was conducted in Bondowoso Regency from August to November 2014. The location was selected deliberately because Bondowoso Regency is the center of coffee production in East Java which has implemented coffee-based economic cluster model. Moreover, the region also received facilities from the government and other stakeholders to empower existing coffee downstream industry and develop new coffee downstream industry. The scope of the study was narrowed to one of its sub-districts, which was Sumberwringin, because there was micro small-scale coffee downstream industry in that region before the implementation of economic cluster model.

\section{Data and Sample Collection}

The method used in this study was survey method. Direct observation on the business units was also conducted to collect information related to business conditions. The method paid attention to data requirements and suitability of respondents' characteristics with research purpose. In this study, data types used were primary and

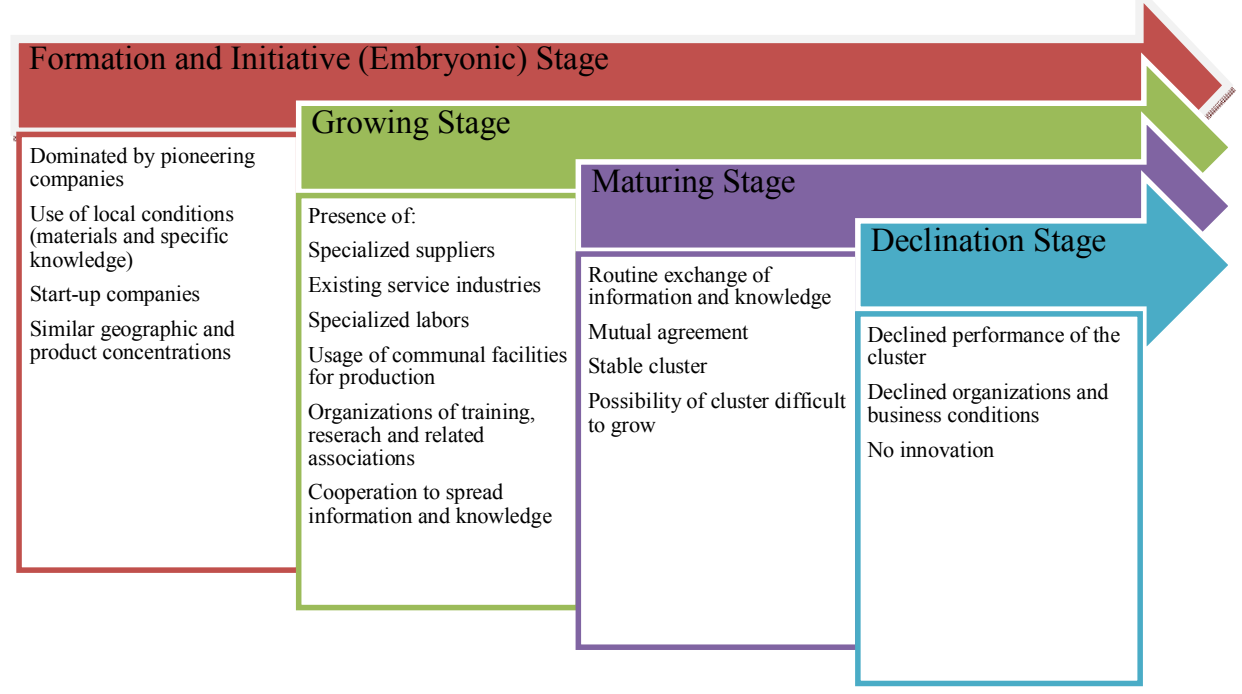

Figure 1. Stages of industrial cluster growth 
secondary data. Primary data was collected by direct interview using questionnaire with micro small-scale coffee downstream industry actors. Primary data included general information related to characteristics of downstream industry, determinants of cluster growth, and strengths, constraints, opportunities, and threats faced in developing businesses. Meanwhile, secondary data was collected by literature study. Secondary data included regional economic potential and framework of dynamic cluster formation to support the discussion of research result which is comprehensively connected with primary data collection in the field. Secondary data was accessed from Bank Indonesia, local related agencies and literature references from various sources.

Respondents in this study consisted of 25 micro small-scale coffee industry actors. Respondents were selected by non-probability sampling approach with judgment sampling or purposive sampling method. This method was selected based on sample characteristic determination adjusted with target population and research purposes or problems (Widyastutik et al., 2010; Primastuti \& Achmad, 2012).

\section{Analysis Method}

Based on the research objective, type of this research was explorative or descriptive research used to collect information and initial data adjusted with research topic. Beside expanding information, explorative study was intended to get new ideas of a phenomenon used as a reference in formulating more detailed problems or hypothesis because there is no hypothesis established to be deduced (Rianse \& Abdi, 2009). Therefore, the method used in this study was qualitative method with descriptive explorative approach. The method was aimed to describe the situation in the field and to study deeply the influencing causes or events (Untari, 2005; Arikunto, 2006). In result description and discussion, the analysis method used was content analysis (Herawati \& Sofhani, 2014; Indarti, 2014). Basically, descriptive explorative study can be used as a basis for future researches (Wicaksono et al., 2012).

\section{RESULTS AND DISCUSSION}

Development of coffee downstream industry in Sumberwringin, Bondowoso Regency started with Coffee-based Economic Cluster Model development initiation in 2010 (BI-Jember \& Puslitkoka, 2010). The first step of this economic cluster model was improving marketing mechanism in the upstream sector which was realized by guidance activities to improve quality and marketing efficiency by Mediated Partnership Model (MOTRAMED) approach. In this economic cluster model, the main targets were farmers/farmer groups which acted as material providers. In the beginning, 5 farmer groups were committed to improve the quality. Then the successful guidance on the 5 farmer groups drew other farmer groups to join the guidance activities, therefore in total there were 37 farmer groups in 2014. With increasing number of farmer groups involved a farmer cooperative was formed as an organization for collective marketing.

The structural improvement in the upstream sector showed significant result because the quality of Arabika coffee which was low improved to grade I, as a result it managed to penetrate export market. The success in managing Arabika coffee encouraged the widespread of guidance activities to improve the quality of Robusta coffee. The guidance activity did not only improve quality and marketing system of coffee upstream sector, but also improved farmers' knowledge and awareness on the importance of quality and 
technology of coffee processing in accordance with standard operational procedure (SOP).

Improved farmers' capacity and knowledge finally encouraged them to develop household-scale coffee downstream industry. Recently, actor components in the cluster are material suppliers, micro small-scale downstream industry, and several supporting industries. Before the implementation of economic cluster model in 2010, there were 9 business units of coffee downstream industry. Along with the implementation of economic cluster program, 16 new business units grew in coffee downstream industry until 2013. This micro small-scale coffee downstream industry is called core industries. The growth of the core industries was due to market growth and positive change in customers' desire in coffee consumption. At the beginning, this household-scale industry only produced coffee powder. However, the industry started to diversify products by producing roasted coffee based on market demands. The development of core industries was based on total business units and product types presented in Figure 2.

\section{Characteristics of Coffee Downstream Industry}

Household-scale coffee downstream industry studied was in Sumberwringin Subdistrict with business locations spread in several urban villages including Sukorejo (44\%), Sukosari (4\%), Sumberwringin (24\%), Rejo Agung (20\%), and Sumbergading $(8 \%)$ urban villages. Business entities in these core industries were all private-owned companies. Most of the industry was run by heads of the families (men) with a percentage of $88 \%$, and the remaining $12 \%$ is managed by housewives.

Based on length of operation, the core industries had varying length of business operation, starting from new industries to industries which had operated for over 10 years. It indicated that the implementation of coffee-based economic cluster model could develop new industries consistent with the core competence. The core competence was related with the availability of natural resources, especially coffee materials. In other words, the industry was close to material

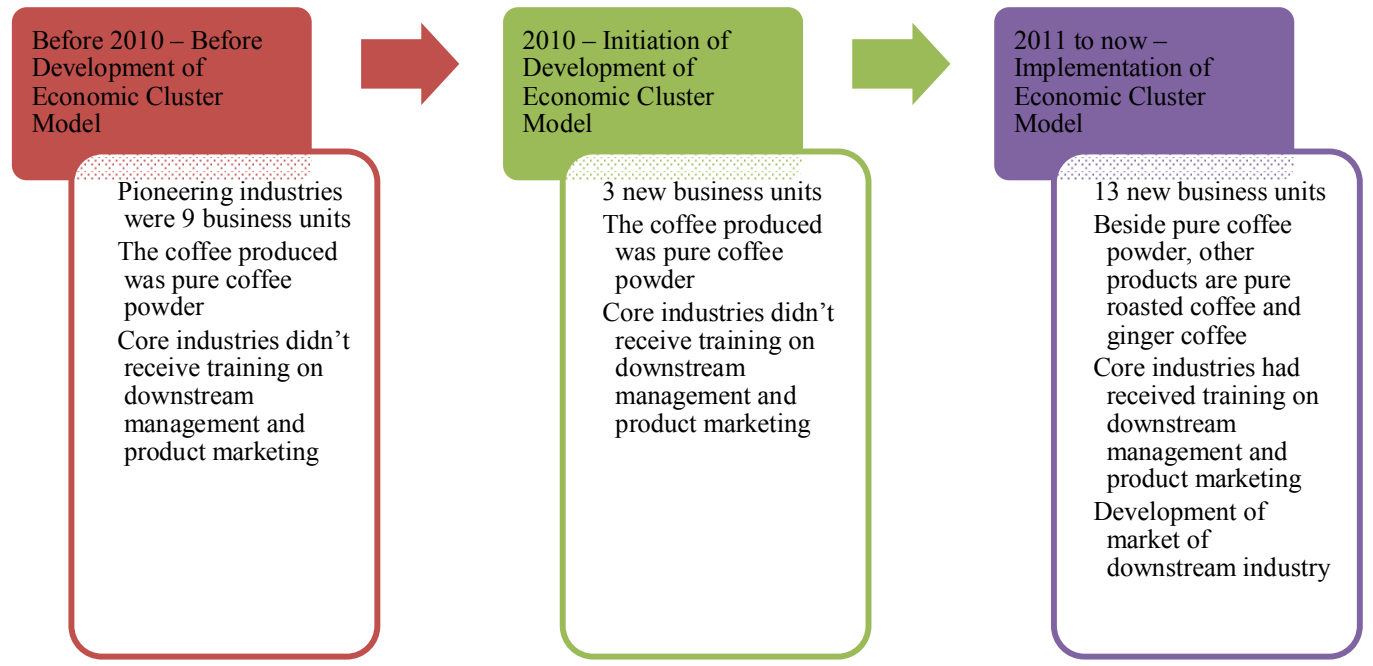

Figure 2. Development of micro and small-scaled coffee industry in Sumberwringin Sub-district based on the number of business unit and type of products. 
sources. Development of industrial cluster adjusted with local core competence will create a competitive and high performance cluster (Robert \& Stimson, 1998 cit Junaidi et al., 2014).

All core industries were categorized as micro small-scale businesses because number of labors was less than 20 people (Supriyati \& Suryani, 2006). The business capital used by the industry was mostly owner/family capital and only a small number used loan capital in running or developing the businesses. Limited use of loan capital was due to assumption that bank loan would burden business owners and the interest rate was quite high. Therefore, although there were sources of funds from banks with small interests, the accesses to capital had not been used by most of the industry (Widyastutik et al., 2010). Most business owners also joined the cooperative. Beside as members, cooperative membership helped the industry to get extra materials from their own plantations, if the quantity was not enough. Detailed characteristics of coffee industry in Sumberwringin Sub-district are presented in Table 1.

Table 1. Characteristics of micro and small-scaled coffee industry in Sumberwringin Sub-district

\begin{tabular}{lc}
\hline Characteristics & Percentage (\%) \\
\hline Form of Business Entity & 100 \\
- Private Company & 0 \\
- Firma & 0 \\
- CV & \\
Length of Operation (years) & 64 \\
- 0-4 & 24 \\
- 5-9 & 12 \\
- 10-13 & \\
Capital & 96 \\
- Private Capital & 4 \\
- Loan Capital & \\
Business Scale & 92 \\
- Micro (1-4 employees) & 8 \\
- Small (5-19 employees) & 0 \\
- Medium (20-99 employees) & 72 \\
Cooperative Membership & 28 \\
- Member & \\
- Non-member &
\end{tabular}

\section{Mapping Determinants of Cluster Growth}

\section{Specialization}

Most of core industries in Sumberwringin Sub-district was micro small-scale enterprises. Consequently the industry did not produced any specialized product. The products made consisted of several items, including coffee powder, roasted coffee and ginger coffee as seen in Table 2. However, most coffee products sold by the industry were pure coffee powder. Coffee production should be based on order and market demand, therefore the products which match consumers interests should be made. However, the difference between this coffee downstream industry and other coffee industries was in the usage of material. Almost all of core coffee industries used Arabika coffee processed by wet process method, while Robusta coffee used dry process. This indicated that the business owners had enough knowledge on coffee processing method in accordance with SOP and quality of coffee beans as materials of drinking products. The coffee materials roasted by each core industry are shown in Table 2.

Table 2. Type of raw materials and coffee products of micro and small-scaled coffee industries in Sumberwringin Sub-district

\begin{tabular}{lcc}
\hline Characteristic & $\begin{array}{c}\text { Total } \\
\text { Industry } \\
\text { (unit) }\end{array}$ & $\begin{array}{c}\text { Percentage } \\
\text { (\%) }\end{array}$ \\
\hline Coffee Material & 21 & 84 \\
a. Wet Processed Arabika Coffee & 17 & 68 \\
b. Dry Processed Robusta Coffee & & \\
c. Blend of Arabika coffee and & 0 & 0 \\
$\quad$ Robusta coffee & & \\
Coffee Product & 0 & 0 \\
a. Roasted Coffee & 21 & 84 \\
b. Coffee Powder & 4 & 20 \\
c. Coffee Powder and Roaster Coffee & 1 & 4 \\
d. Ginger Coffee & & \\
\hline
\end{tabular}




\section{Research and Development Capacity}

Concerning research and development activities, the core industries had not carried out that activities, therefore the products were limited and they only used their own new technology. Nevertheless, this coffee downstream industry had easy access to innovation and technology from various agencies such as research and development institutions and related departments. The easy access was due to partnership in coffee-based economic cluster modeling. This modeling involved seven stakeholders which facilitated cluster development. Stakeholders acted as facilitators for core industries in terms of capital, facilities and infrastructures and technology transfer. Research and development institutions which supported the cluster in technological transfer were Indonesian Coffee and Cocoa Research Center (Puslitkoka) and Forestry and Plantation Services (Dishutbun) of Bondowoso Regency. The institutions provide various facilities in research and development, especially transfer of processing technology and machineries, as well as understanding on quality of coffee beans are good as materials of drinking products. The guidance activities helped the industry to adopt downstream processing technology more effectively. Therefore, close relationship between coffee downstream industry with research and development institutions is crucial in developing industrial clusters (Rosenfeld, 1997). Without innovation in the formation of industrial clusters, the industry will have difficulty to develop a competitive industrial cluster (Bappenas, 2004).

\section{Knowledge and Skill}

In economy theories, labor is one of the important production factors in running production activities in an industry. However, in reality, labors in micro small-scale industries generally have low education.
Besides, their knowledge and skill in industry are also limited (Rosenfeld, 1997). This condition also happen in micro smallscale coffee downstream industry in Bondowoso Regency. Before implementation of economic cluster model, the knowledge and skill of labors in micro small-scale industry was still low. This condition was reflected from production knowledge and skill of industry actors which were acquired from generation to generation with simple processing technology. Industry actors also had not receive any training of roasting and good roast level of coffee beans to have good taste. Beside production skill, industry actors also had limited knowledge on business management and marketing network of coffee products. This condition was also faced by several industrial clusters studied by Bappenas (2004).

Implementation of economic cluster model provided opportunities for industry actors to receive informal education and training related to the management of coffee downstream and product marketing. This increased the capacity of industry actors in developing their businesses because there were knowledge and technological transfers from partnership with research institutions (Puslitkoka) in economic cluster model because labors require knowledge and skill on the management of coffee downstream in accordance with GMP in the production stage to meet consumers' demands. The closeness of the cluster with Puslitkoka in Jember benefited industry actors in getting direct facilitation in solving their problems. Related to knowledge on quality and marketing, several business actors also received trainings from Industry, Trade and Cooperative Services (Disperindagkop) and Health Services (Diskes) of Bondowoso Regency. Improved skill of labors is necessary for the success of developing business-oriented industrial cluster. This finding was supported 
by the study of Bertini (1994) on an industrial cluster in Italy cited by Rosenfeld (1997), which showed that labors had to have specific knowledge and skills in using production technology, product marketing and consumers' needs and interest for the success of the formation of profit-oriented industrial cluster system.

Beside guidance and training, industry actors also tried to improve their knowledge and skills in various ways. Each industry actor has its own way to improve its capacity. Most actors used good relations with friends and counselors to get information to improve knowledge and skills. Based on the survey, industry actors' efforts to improve knowledge and skills are shown in Table 3.

Table 3. Efforts for improving knowledge and skills carried out by industry players

\begin{tabular}{lcc}
\hline Effort & $\begin{array}{c}\text { Total Industry } \\
\text { (Unit) }\end{array}$ & Percentage, \% \\
\hline Reading & 11 & 44 \\
Asking friends & 22 & 88 \\
Asking counselors & 19 & 76 \\
Watching television & 13 & 52 \\
Asking buyers & 2 & 8 \\
Using internet & 3 & 12 \\
Comparative study & 1 & 4 \\
\hline
\end{tabular}

\section{Human Resources Development}

Coffee downstream industries in Bondowoso Regency were mostly micro small-scale industries, therefore they have limitation in developing local human resources capacity. Development of human resources was not performed by core industries but facilitated by guiding institutions in economic cluster model. The facilities were guiding, training and mentoring, especially for coffee farmers and coffee downstream industry actors. These activities are required by local community, especially industry actors, because the core industries did not have specific job in production activities and the management was still simple. Labors that performed production process came from their families and only small number of the industries employed labors from outside of their families.

Basically, the coffee downstream industry could grow if their human resources have special skills in production process, especially roasting and tasting. The skills could be obtained by training and guiding carried out by Puslitkoka and facilitated by guidance institutions. However, some industry actors claimed that they had never received guidance and training. Information on guidance and training is shown in Table 4. Downstream management skill is vital to meet market demands for coffee drinking products and effort to grow business scale, because roasting level and taste of coffee are related to consumers' taste and preferences. Therefore, availability of training and guidance on coffee downstream processing are important and are an opportunity for coffee downstream industry to get informal education and facilities in adopting technology and business management. Providing of training and guidance is in line with the concept of Prayitno (2011) on the role of intermediary institutions in developing UMKM. Intensive training and guiding activities was proved to be effective in technology transfer, in order

Table 4. Facilities provided by stakeholders to micro and small-scaled coffee industries in Sumberwringin Sub-district

\begin{tabular}{lccc}
\hline Facility & $\begin{array}{c}\text { Total } \\
\text { Industry } \\
\text { (Unit) }\end{array}$ & $\begin{array}{c}\text { Percentage } \\
(\%)\end{array}$ & Facilitator \\
\hline
\end{tabular}

\begin{tabular}{lrrl}
\hline $\begin{array}{l}\text { Training } \\
\text { a. Never }\end{array}$ & 9 & 36 & \\
b. Trained & 16 & 64 & $\begin{array}{l}\text { - Puslitkoka } \\
\text { - Disperindag } \\
\text { - Diskes }\end{array}$ \\
Guidance & & & \\
a. Never & 2 & 8 & \\
b. Guided & 23 & 92 & $\begin{array}{l}\text { - Government } \\
\text { - Puslitkoka }\end{array}$ \\
& & & - Dishutbun \\
& & & - BI Jember \\
& & & - Diskes \\
\hline
\end{tabular}


that it could be absorbed by industrial actors more easily because there was two-way communication between the actors and facilitators. Clusters which provide education and training programs will be able to develop capacity of local community involved in coffee downstream industry (Rosenfeld, 1997).

\section{Closeness to Supplier}

Based on productive resources, potential competitive commodities in the survey location were Arabika coffee and Robusta coffee. However, development of commodities in the economic cluster tended to focus on Arabika coffee. In order to grow industrial cluster, backward linkage effect by developing coffee community in the upstream sector was necessary. Generally, development of coffee upstream sector was focused on improving potential regional productions and improvement of quality. This program was performed on the early implementation stages of economic cluster model to get primary product materials which matched with market demands. Improved production and quality of coffee bean guarantee the continuity of supply and commitment to buyers/ exporters.

Based on that condition, it was discovered that the core industries had closeness with material sources. It is supported by the fact in the field that most industry actors were farmers, therefore material requirements for coffee downstream products were fullfilled by their own plantations. Although the materials came from their own plantations, some industry actors obtained their raw materials from members of farmer groups or farmer cooperative. It was concluded that coffee beans derived from material suppliers in the cluster, consequently development of this industrial cluster was oriented to the closeness to the material sources
(Siagian \& Santoso, 2013). It should be noted that what should be considered in developing highly competitive industrial cluster is closeness to material suppliers (Rosenfeld, 1997). In this case, material suppliers (farmers, farmer groups, farmer cooperative) were in the cluster therefore industry actors could easily access the materials. The origins of coffee beans used by industry actors as materials of coffee products are shown in Table 5.

Table 5. Origin of coffee bean as raw materials of coffee products

\begin{tabular}{lcc}
\hline Origin of coffee bean & $\begin{array}{c}\text { Total industry } \\
\text { (unit) }\end{array}$ & $\begin{array}{c}\text { Percentage } \\
(\%)\end{array}$ \\
\hline Local & 25 & 100 \\
Out of Region & 0 & 0 \\
\hline
\end{tabular}

According to Pakasi (2013), supplier network structure did not only involve farmers as primary material suppliers, but also financial institutions and other supporting industries which contributed to increase production. Those institutions play a role in solving technical problems in the field to increase production capacity by introducing new technologies to farmers, as well as to industries. This supplier network structure had been applied in coffee-based economic cluster program in Bondowoso since 2011. In that program, the first supplier structure reformed was primary material suppliers, in this case farmers. This was because the coffee bean produced by farmers tended to be low in quality with simple processing. The low quality primary materials caused variations of quality and taste of coffee downstream products. The improvement in this upstream sector was successful by improving the processing thus quality of coffee beans produced getting better. To improve upstream and downstream sectors, suppliers developed social capital in strong commitment to maintain the continuation of production supply, especially for exporters and industries. 


\section{Capital Availability}

For industries, capital is an important production factor to perform production activities and maintain business continuity. In economic cluster program, banking institutions are some of supporting industries committed and agreed to provide capital for farmers and micro small-scale industry actors. However, the business capital scheme was focused on improving the upstream sector therefore the actors in the downstream sector did not have full opportunity to access the capital. This condition was supported by the fact in the field where most industries actors used private or family capital, as shown in Table 1. Only one business unit used capital from bank. This situation was consistent with the study of Bank Indonesia (2005) cit. Widyastutik et al. (2010) which stated that most of UMKM funding sources came from private and family capitals, although access to business credit was widely available. Munizu (2010) also stated that industry actors generally start their businesses and expand the business scale using private/family funding sources. Available capital had not been used by most industry actors because they believed that bank loan would burden their financial system. However in principal, the core industries require credits to increase production capacity and expand business network. In this economic cluster, banking institutions had provided business credits with small interest rates, as a result the credits could be accessed by coffee farmers and micro small-scale coffee industry actors.

\section{Cooperation Network and Social Capital}

Based on cooperation network, economic cluster program was formed by partnership system between core industries and supporting industries. However, the current partnership pattern was still on primary product supply stage. In other words, collective production and marketing activities were still practiced at farmer group level by forming cooperative. The cooperative helps farmers to share orders, technology and information. Meanwhile in downstream industry, cooperation had not been formed, thus product marketing was performed individually. Downstream industry also had not established cooperation with large industries/factories to supply materials such as roasted coffee and coffee powder. Coffee products from the downstream industry were still marketed locally. The coffee products also could not compete with large industries/factories because the packaged coffee powder product market was very competitive.

In terms of social capital, the business cooperation mechanism in the cluster strongly based on social capital, such as norms, beliefs, cooperation and mutual cooperation. The social capital started at the beginning of cluster development of the upstream sector. This social capital is expected to be maintained because social capital significantly influences the formation of industrial clusters (Widyastutik et al., 2010). Although there was social capital, its influence on the development of industrial cluster still could not be seen. This was shown by the poor cooperation between core industries.

\section{Entrepreneurship}

Economic agents, especially farmers, had high entrepreneurship spirit after the success in improving quality and marketing of coffee bean products. This was shown by their interest in using opportunities to develop new businesses in downstream industry. New downstream industry grew in the cluster to fill the gap of coffee downstream product market. The development of downstream industry is shown in Figure 2. Entrepreneurship spirit was also reflected in their efforts to diversify products. Initially, the only product 
was coffee powder with varying quality of coffee bean materials. However, now industry actors try to target new markets such as coffee shops by producing roasted coffee. Coffee powder and roasted coffee were produced using Arabika coffee (pure), Robusta coffee (pure), and a blend of Arabika coffee and Robusta coffee. The quality of the materials was high because it was adjusted with consumers' demands which grew in terms of demand and requirement. Besides, industry actors also created other products such as ginger coffee. High motivation and entrepreneurship are some of the main capitals in growing businesses and developing industrial clusters (Munizu, 2010). With the growth of the industry, there is potential at the survey location to create dynamic industrial cluster.

\section{Leadership and Common Vision}

Although social capital availability was quite high, there was no shared commitment to develop industrial cluster. It was shown by the lack of business or industrial leader associations, as a result the core industries did not have any common vision. Furthermore, each industry actor had not reached agreement in determining the brand of coffee products of the coffee downstream industry. On the other hand, guiding institutions suggested a brand of downstream products for the entire industry but this had not been agreed by industry actors. It showed that the core industries could not create a system among the actors to plan production and business negotiations together. The same condition happened to kemplang cracker industrial cluster in Palembang which was studied by Maulidin (2014). The industrial cluster also did not have any industry leader which could act as an innovator and motivator for the core industries. Wijaya (2015) stated that the development of an industrial cluster requires leadership and clear vision in the long term to be successful in developing the cluster.

Based on the mapping of the nine factors, it was concluded that industry actors in the cluster were not connected in material supply and marketing. Each core industry managed the business without involving other core industries. On the other hand, the core industries were connected with supporting industries including Dishutbun of Bondowoso Regency, BI Jember, Puslitkoka, and Bank Jatim Branch of Bondowoso. However, the benefit of banking institutions had not been utilized by most of the core industries. Development of cooperation with large companies also had not been performed by the core industries. At this stage, it was clear that it is not easy to connect the core industries with large industries/factories because large industries/ factories generally produce their own coffee products, thus the product required by the industries was coffee beans as raw materials. Therefore, it showed that the growth of downstream industrial cluster in Bondowoso Regency was still at the formation and initiative phase (embryonic) as shown in Figure 3. Criteria descriptions are the same as Figure 1.

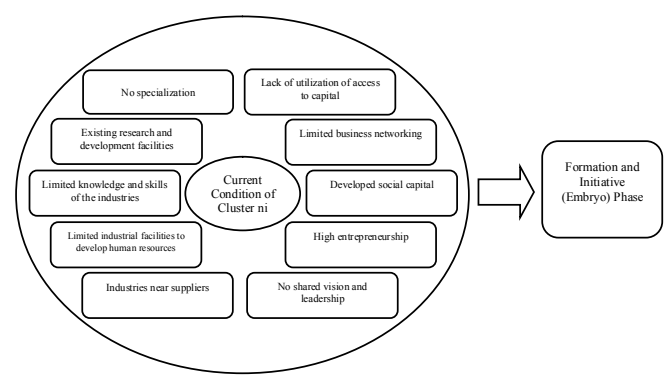

Figure 3. Phase of industrial cluster growth of micro and small-scaled coffee industries in Bondowoso District. 
In terms of growth pattern, the growth processes of the cluster would have different patterns. According to Untari (2005), identification of cluster growth pattern can be seen in change of total core industries, change of size of core industries, specialization of supporting industries, and change of size of supporting industries in the cluster. The situation in the field showed that the growth of the industrial cluster was based on the change of total core industries and business size of the core industries. During the implementation of economic cluster model, number of core industries grew. Increasing core industries was due to external environment, especially the market and active participation of guiding institutions which provided external economies. However, the size of each industry did not change because most of core industries performed production process based on orders from buyers. This result was categorized in Pattern III of four cluster growth patterns stated by Untari (2005). The pattern showed that total core industries in the cluster grew during the development but the size/scale of the industries did not change.

In developing the businesses, core industries should consider strengths, opportunities, constraints, and threats when making decisions because identification of the four factors can be used to determine the direction of development of downstream industry. Based on the research result, most industry actors $(72 \%)$ stated that availability of materials was one of the strengths of the research location which could be used to take advantage of opportunities which were reflected in growing market of coffee downstream products due to lifestyle change in the society in coffee consumption. This market opportunity was considered by industry actors $(60 \%)$ as a driving factor in opening new businesses in coffee down- stream processing. Beside market, strength and opportunity considered important for the industry was easy access to UMKM credit. However, this facility had not been widely used by core industries to increase capital in expanding businesses. Moreover, some industry actors revealed other strengths and opportunities which were supporting facilities (4\%) and availability of labor (4\%).

In terms of constraints and threat, the identified factors included marketing $(68 \%)$, capital (44\%), machine equipment (56\%), quality of material $(24 \%)$, collection of account receivables (4\%), competitor (4\%), and quality (4\%). The result showed that marketing was still one of the constraints faced by most industry actors. The core industries had limited access to cooperate with large industries/factories. Therefore, the core industries marketed coffee products individually in small scale. This was solved partially by using supporting facility, which was marketing service. The core industries could cooperate with subcontractors/ distributors in marketing of products. Efforts to solve marketing limitations would be efficient if the core industries marketed the products together.

Condition of machine equipments and capital was also a constraint and threat which should be noted by the core industries. Both were supporting facilities required to maintain and grow the scale of the businesses. The condition of machine equipment would impact on production capacity and quality of coffee, while capital was required to maintain production process. The quality of materials and taste was related with consumers' taste thus it would impact the volume of sales of the core industries. Competitors also gave a risk to the core industries because it could narrow the market segment which could be entered by the core industries. Several core industries had difficulty in collecting account receivables 
from buyers. It led to discontinuity of production process, especially in meeting capital requirement to maintain production activities. This could be solved by accepting purchasing in cash, while production process could be maintained by using UMKM credit facilities with small interest rates.

Unlike previous cases, some industries $(16 \%)$ stated that they never faced constraints and threats while running the businesses.
However, the statement was asked again to industry actors because most industries will meet constraints and threats in developing the businesses. The result showed that industries faced problems related to lack of available machine equipments, poor product quality and small scope of market segment. Various identified strengths, opportunities, constraints and threats faced by the core industries are shown in Figure 4.
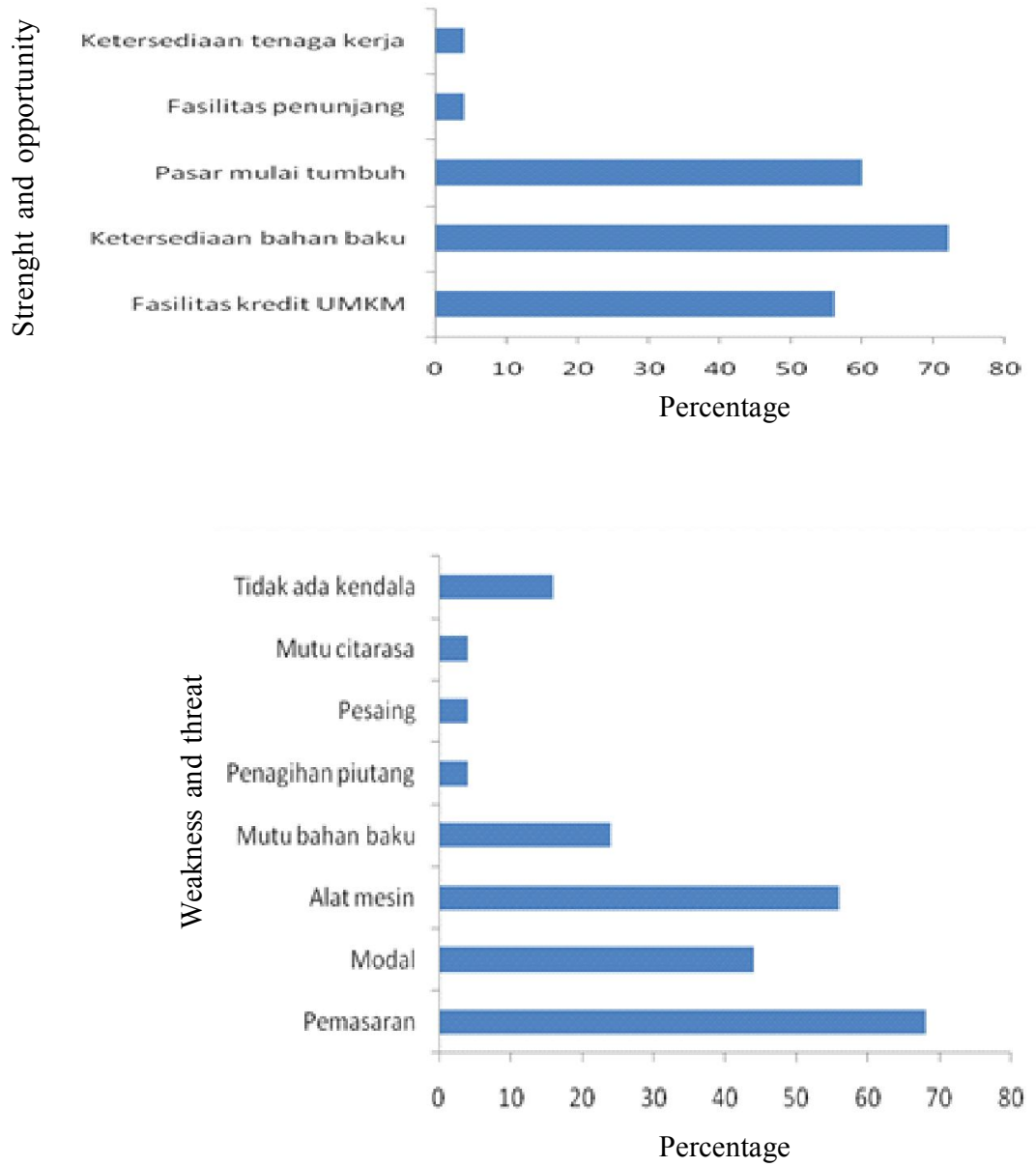

Figure 4. Identification results of systematic factors that included in strength, opportunity, weakness and threat variables for industry development in Bondowoso District. 


\section{CONCLUSION}

The industrial cluster in Bondowoso Regency was in formation and initiative stage (embryonic) with growth pattern consistent with Pattern III. There was no interrelation between core industries in the cluster, while the relation between the core industries and supporting industries was good. Strengths and opportunities in developing coffee industry included availability of materials, growth of market segment, UMKM credit facilities, supporting facilities, and availability of labors. Constraints and threats faced by the coffee industry included limited marketing access, equipment and machine facilities, capital, quality of materials, product quality, collection of account receivables, and competitors.

\section{ACKNOWLEDGEMENT}

The author would like to thanks Department of Forestry and Plantation of Bondowoso Regency and Jember Bank Indonesia which had contributed to the funding and performance of this study.

\section{REFERENCES}

Aklimawati, L.; D. Sumarno \& S. Mawardi (2015). Pengaruh kualitas pelayanan dalam pembangunan klaster ekonomi berbasis kopi terhadap kepuasan petani dan pemangku kepentingan lainnya di Kabupaten Bondowoso. Pelita Perkebunan, 31, 59-72.

Arikunto, S. (2006). Prosedur Penelitian Pendekatan. Rineka Cipta, Jakarta

Bappenas (2004). Kajian Strategi Pengembangan Kawasan dalam rangka Mendukung Akselerasi Peningkatan Daya Saing Daerah. Direktorat Pengembangan Kawasan Khusus dan Tertinggal. Badan Perencanaan Pembangunan Nasional, Jakarta.
BI-Jember \& Puslitkoka (2010). Kajian Pembentukan Klaster Industri Kopi di Kabupaten Bondowoso. Kerjasama Bank Indonesia Jember dengan Pusat Penelitian Kopi dan Kakao Indonesia. Laporan Internal.

Demirbag, M.; E. Tatoglu; M. Tekinkus \& S. Zaim (2006). An analysis of the relationship between TQM implementation and organizational performance: evidence from Turkish SMEs. Journal of Manufacturing Technology Management, $17,829-847$.

Djamhari, C. (2006). Faktor-faktor yang mempengaruhi perkembangan sentra UKM menjadi klaster dinamis. Infokop, 29, 83-91.

Herawati, R. \& T.F. Sofhani (2014). Mendorong peran perguruan tinggi dalam meningkatkan inovasi dan keterkaitan antar aktor di Sentra Industri Logam Ngingas. Jurnal Perencanaan Wilayah dan Kota B, 3, 693-698.

Indarti, I. (2014). Tantangan usaha mikro kecil dan menengah dalam menghadapi Asean Economic Community 2015. $3^{r d}$ Economics \& Business Research Festival, p. 1013-1028. Salatiga, Indonesia.

Junaidi; A. Amir \& Hardiani (2014). Potensi klaster agroindustri usaha mikro kecil dan menengah di Provinsi Jambi. Jurnal Perspektif Pembiayaan dan Pembangunan Daerah, 2, 9-20.

Maulidin, D. (2014). Strategi optimalisasi klaster industri kecil kerupuk kemplang di kota Palembang. Prosiding Seminar Nasional Hasil-hasil Penelitian dan SILATNAS IV FORDEBI, p. 649-676. Palembang, Indonesia.

Munizu, M. (2010). Pengaruh faktor-faktor eksternal dan internal terhadap kinerja usaha mikro dan kecil (UKM) di Sulawesi Selatan. Jurnal Manajemen dan Kewirausahaan, 12, 33-41.

Pakasi, C.B. D. (2013). Pengembangan kelapa sebagai komoditi unggulan daerah 
Sulawesi Utara dengan pendekatan klaster industri. Seminar Nasional Menggagas Kebangkitan Komoditas Unggulan Lokal Pertanian dan Kelautan, p. 250-265. Fakultas Pertanian, Universitas Trunojoyo Madura, Indonesia.

Porter, M.E. (1990). The Competitive Advantage of Nations. The Free Press, New York.

Prayitno, K.B. (2011). Peran lembaga intermediasi (LI) dalam pengembangan UMKM inovatif. Jurnal Sistem Inovasi, $1,1-11$.

Primastuti, S. \& T. Achmad (2012). Pengaruh corporate governance dan karakteristik perusahaan terhadap luas pengungkapan informasi strategis. Diponegoro Journal of Accounting, 1, 1-15.

Rianse, U. \& Abdi (2009). Metodologi Penelitian Sosial dan Ekonomi: Teori dan Aplikasi. Alfabeta, Bandung.

Rosenfeld, S.A. (1997). Bringing business clusters into the mainstream of economic development. European Planning Studies, 5, 1-22.

Siagian, A.P. \& E.B. Santoso (2013). Klaster pengembangan industri berbasis perkebunan dalam pengembangan wilayah di provinsi Aceh. Jurnal Teknik POMITS, 2, 78-82.

Sudaryanto; Ragimun \& R.R. Wijayanti (2013). Strategi Pemberdayaan UMKM Menghadapi Pasar Bebas Asean. Pusat Kebijakan Ekonomi Makro. Badan Kebijakan Fiskal. Kementerian Keuangan, Jakarta.
Supriyati \& E. Suryani (2006). Peranan, peluang dan kendala pengembangan agroindustri di Indonesia. Forum Penelitian Agro Ekonomi, 24, 92-106.

Suryono, A. (2012). Peranan dan Pemanfaatan Modal Sosial dalam Pengembangan Klaster: Studi pada Klaster Cor Logam Ceper - Klaten Jawa Tengah. Disertasi, Universitas Kristen Satya Wacana, Salatiga, Indonesia.

Untari, R. (2005). Pola Pertumbuhan Klaster Industri Kecil Indonesia. Disertasi, Institut Teknologi Bandung, Bandung, Indonesia.

Wicaksono, S.; G. Widianingsih \& S.T. Hartati (2012). Struktur vegetasi dan kerapatan jenis lamun di perairan kepulauan Karimunjawa, kabupaten Jepara. Journal of Marine Research, 1, 1-7.

Widyastutik; H. Mulyati \& E.I.K. Putri (2010). Analisis faktor-faktor yang mempengaruhi pengembangan klaster UMKM alas kaki di kota Bogor yang berdaya saing. Jurnal Manajemen \& Agribisnis, 7, $16-26$.

Wijaya, S.A.A. (2015). Studi peranan klaster industri, hambatan bisnis, dan kepemilikan asing terhadap intensitas kapital di Indonesia. AGORA, 3, 1-5.

$$
* * 0 * *
$$

